\title{
Alluvial nodular monazite in Monfortinho (Idanha-a-Nova, Portugal): Regional distribution and genesis
}

\author{
Rute Salgueiro $^{\mathrm{a}, *}$, Carlos Inverno ${ }^{\mathrm{a}}$, Daniel P.S. de Oliveira ${ }^{\mathrm{a}}$, Fernanda Guimarães ${ }^{\mathrm{b}}$, \\ José Lencastre ${ }^{\mathrm{a}, \dagger}$, Diogo Rosa ${ }^{\mathrm{c}}$ \\ ${ }^{a}$ Laboratório Nacional de Energia e Geologia (LNEG), Mineral Resources and Geophysics Research Unit, Ap. 7586, 2611-901 Amadora, Portugal \\ ${ }^{\mathrm{b}}$ LNEG, Mineral Science and Technology Unit, Ap. 1089, 4466-901 S. Mamede de Infesta, Portugal

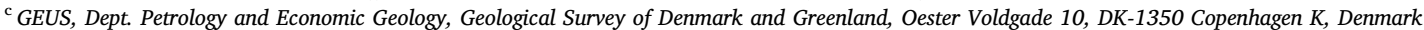

\section{A R T I C L E I N F O}

\section{Keywords:}

Nodular monazite

Alluvial distribution

Genesis

REE

Monfortinho (Portugal)

\begin{abstract}
A B S T R A C T
This work constitutes a contribution to the knowledge on the occurrence of nodular monazite in the Monfortinho (Idanha-a-Nova) alluviums and its genesis. A new edition of the alluvial nodular monazite regional distribution map is presented, underlining its wide occurrence and preferential concentration in the north-western and central zones of this region. The assessment of the geological and environmental evolution during Neoproterozoic-Palaeozoic and Caenozoic times and alluvial nodular monazite accumulation seems to provide a direct association between the presence of the Ordovician rocks, in particular the radioactive (carrying radioactive heavy minerals) quartzite (one of the most probable original sources) and Caenozoic sedimentary rocks (most probably the secondary source). Nevertheless, the Slate-Greywacke Complex cannot be excluded as a host rock for nodular monazite as well. Alluvial heavy mineral concentrates include: iron oxide/hydroxide, ilmenite, tourmaline, nodular monazite, monazite, xenotime, zircon, rutile, anatase, brookite, apatite, andalusite, gold, cassiterite and topaz. There is a significant REE enrichment in these concentrates (up to $>32,000 \mathrm{mg} / \mathrm{kg}$ ), mainly in LREE-MREE. The contents in Ce and Th, Th and REE and Ce and La showed good correlation (0.97, 0.96 and 0.99 , respectively), reflecting mainly the striking presence of nodular monazite, as can be proved by the similarity among $\mathrm{NASC}_{\mathrm{N}}$ patterns of this mineral and concentrates. In Monfortinho there are two distinct alluvial nodular monazite populations: 1) distal pre-deformation nodules generation, from the central western area, mostly ellipsoidal to discoidal, with irregular not orientated probable detrital mineral inclusions; and 2) proximal generation, in the northern area near the Ordovician rocks, with smaller grains, with mostly irregular surfaces. Diagenetic/low metamorphic pre-deformation distal Monfortinho nodules population growth can be recognised and characterised by the encompassing of irregular unoriented mineral inclusions of the host matrix rock; preferential incorporation of MREE over other REE in the core nodules, consistent with diagenetic MREErich environmental/mineralized fluids supplied by the dehydration of Variscan sedimentary marine sequences with phosphatic rocks, at the start of nodule formation. The slight increase in Ca towards the nodule rims denotes a relative increase in fluid salinity during nodule growth, consistent with the ineffectiveness of metamorphic dewatering in dissolving the significant salt content of those marine sequence(s); Th increment in nodule rims points to the temperature increment at this stage; its moderately to pronouncedly negative Eu anomalies and the general involvement of the cheralitic substitution mechanism are characteristic of metamorphic monazites. Monfortinho and other published data suggest that in the beginning of nodular monazite formation the fractionation $(\mathrm{La} / \mathrm{Sm})_{\mathrm{N}}$ tended to be lower than that of the original source (detrital relic mineral/ seawater), very similar to primary synsedimentary apatite or to monazite nodules interpreted to have precipitated directly from seawater. At the end the fractionation values can be substantially higher than those and may be dependent on the conditions established during the different geologic environments. The persistence of the ideal conditions (local P-T and fluid chemical composition evolution) to nodule growth, during Variscan diagenetic and metamorphic events, turned possible that Monfortinho monazite nodules record a relative high range of fractionation values $\left[(\mathrm{La} / \mathrm{Sm})_{\mathrm{N}}=0.08\right.$ to10.40].
\end{abstract}

\footnotetext{
* Corresponding author.

E-mail address: rute.salgueiro@lneg.pt (R. Salgueiro).

Deceased.
} 